\title{
Engage, Dis-Engage and Re-Engage: Analysing Beijing-Delhi Relations since the Post-Cold War Period
}

\author{
Pervaiz Ali Mahesar ${ }^{1}$, Ali Khan Ghumro ${ }^{2}$, \\ and Abdul Hameed Mahesar ${ }^{3}$
}

\begin{abstract}
China and India are interlinked through their civilization, culture, economy, trade, and technology. Their interactions are increasing yet constrained by certain political and territorial disputes. The current state of their relations appears to be disengaged by the events, such as Chinese blockage of Indian entry into NSG (Nuclear Suppliers Group) in 2016, and their military confrontation at Doklam plateau in the year 2017, re-engaged at Wuhan on April 28, 2018, but again dis-engaged due to conflict at Ladakh (Galwan Valley) 2020, shows how their relations have engaged and disengaged. This paper examines how both states have engaged, disengaged, and re-engaged since the Post-Cold War period. The study finds that both countries have huge potential and opportunities to expand and deepen their economic and trade ties not only for their mutual interest but also for the region at large. It concludes that the nature of their relations would remain highly competitive in terms of trade and economy, oil, and energy, gaining status, and influence at the regional and global levels.
\end{abstract}

Keywords: China; India; Engagement; Estrangement; South Asia; Look East Policy.

\section{Introduction}

The fate of Asia is interlinked with how Beijing-New Delhi interacts with each other on regional issues including their economic and political disputes. Both are rising economic giants, with enormous potential for the market, seeking superpower status at the regional and global levels. Their headway in science and innovation, mutual visits for trade and investment manifests their improving nature of the relationship.

If we look at the regional dynamics, India seems to dominate in South Asia. However, the deeper examination of facts speaks a different story in which China is considered to be having a vital role in the region. Discourses on China and India suggests that these powers adopt different policy frameworks towards other regions, including South Asia. The evolving geopolitical events in the region suggests that "India is at a structural disadvantage to China in the region" (Wagner, 2016). Sporadic clashes along the border since 1962 leaves a great question mark on the minds of both countries. After all, such events had left a negative impact on their ties.

\footnotetext{
Department of Political Science, University of Sindh Jamshoro, Pakistan.

Department of Int, Relations, University of Sindh; and University of Malaya, Malaysia.

Deptarment of Criminology, University of Sindh Jamshoro, Pakistan.
}

*)Corresponding Author.

Email: pervaiz_mahesar@yahoo.com 
Currently, China and India are much talked about in the media due to India's nuclear agreement with America and its Look East policy.

Both countries have a long history, vastness of their territories, and have gone through Western colonialism. Their development experiences are being explored and studied as a part of development studies (Bhalla, 2000). Some experts believe that there are still scant studies on their comparative studies. Generally, studies on China-Pakistan relations highlight their border dispute. Despite investing billions of dollars in each other countries, the level of trust has not been satisfactory (Hoffmann 1999; Maxwell, 1981). As indicated in one of the studies of Martin Lionel (2004), "Beijing believes that India is a regional hegemon and competitor". Further, analysts argue that India is being supported by Washington and Tokyo, hence, it is feared that this growing triple alliance might complicate New Delhi's ties with China. Whereas, the Indian strategic community perceives the Chinese military and economic support as unhappy development for them. It should be noted that both the powers (India and China) are vying for influence and great power status in the region. This paper seeks to examine key factors in the engagement and estrangement of China-India relationships since the Post-Cold War era.

\section{Reciprocal Interaction Between India and China}

The relations between India and China have often been reciprocal. These interactions formally were initiated after Rajiv Gandhi's brief state sojourn to Beijing in December 1988. His visit was termed as a step towards the melting of the ice. After that many state-level visits were exchanged (Mansingh \& Levine, 1989). The reports showed that there has been a reciprocal exchange of visits that ranges from the presidential, prime ministerial, parliamentary, political party, academic, economic to defense levels (Indian Ministry of External Affairs, 2011 ). After thirty-one long years, the Prime Minister of China, Li Peng visited India and it was followed by an Indian President Ramaswamy Venkataraman's visit to China. Similarly, President of China Jiang Zemin (1996), President Narayanan (2000), Li Peng-Chairman of the Standing Committee of National Peoples China (2001), Prime Minister Zhu Rongji (2002), Prime Minister Vajpayee (2003), and Prime Minister Wen Jiabao (2005) have exchanged their visits to each other country. These bilateral exchanges had paved the way forward for their rapprochement in their relations.

The landmark visit of Premier Wen Jiabao in 2005 showed that there was an ample desire for learning from each other. Further, the increasing frequency of meetings between Indian and Chinese leadership is indeed manifested in their agreements and co-operations on various important matters. For instance, oil and gas resources at a global level. In June 2014, Wang Yi makes a landmark visit to India. He holds talks with Sushma Swaraj, Modi, and these exchanges were reciprocated in the form of India's Vice President, Hamid Ansari's, five-day visit to China. Similarly, in July 2014, Bikram Singh, Indian Army Chief, went on a three-day trip to China. This meeting later on 
culminated into a Modi meeting with Xi at the side-lines of the BRICS summit that was held in Brazil. Narendra Modi, Prime Minister of India, while talking to the Chinese New Delhi based journalists, expressed that: historical and cultural values bind both neighbors together. Collectively, they can contribute to the well-being of the people. For instance, thirty-five percent of the world population are getting a benefit, because of its closeness to two powers. Hence, these people's lives can be transferred due to the economic interaction of two regional powers.

In March 2015, an important meeting was held between Doval, National Security Advisor from the Indian side, whereas, Yang Jiechi was from the Chinese side. They both discussed the boundary issue. However, later on, these meetings were followed by the Modi-Xi meeting at the sidelines of the Goa BRICS Summit. Despite these mutual state-level exchanges, in May 2017, India did not attend Belt and Road Initiative (BRI) summit. Portrayed as 'emerging markets and largest developing states', China and India are considered as the linchpin for the growth and economic development in the multipolar and globalized world. Their collective efforts would largely contribute towards the eradication of poverty and inequality from the face of the earth (Pant, 2018).

\section{A Brief Interlude in Relations}

Although the Nehru-Enlai meeting in 1954 was credited to have put the foundation stone for the mutual relationship between Beijing and Delhi. Their cordial relations could be seen from their mutual commitment to the Five Principles for the Peaceful Co-Existence. These five principles for peaceful coexistence include mutual respect, non-aggression, non-interference, mutual equality and benefit, and peaceful co-existence. However, this cordiality in their ties could not last long. It is a fact that India and China share the longest and conflicting borderline. This line is so complex and sensitive for it is not clearly defined. "The undemocratic and undecided status of the boundary has inevitably given birth to an unending dispute between India and China" (Garver, 2001).

If we look back to 1959, Zhou Enlai in his befitting response to Indian leader, Nehru, had explicitly turned down the contesting point that it was demarcated based on a treaty and convention. The Chinese leadership further explained that they never accepted what was generally called Mac Mohan Line as planned by the UK at the Shimla meeting (1913-14). He further opined that the Boundary map developed by the UK reflects that the eastern part of the borderline was contested by the Chinese. In addition to this, it was claimed by the Chinese Premier Zhou Enlai that Tibet and other areas that are in proximity to the same area were considered to be an integral part of China. These claims and counterclaims showed that the Delhi-Beijing relations were confounded due to the undecided status of their borders.

As back as 1959, the clashes at the border had erupted which resulted in the worsening of the situation. India claimed that the road leading to Aksai 
China was cut by China. After this, India adopted a forward approach in its policy. It means that India had stationed its troops at forwarding positions. These steps were of grave concern to the Chinese. It was reported by the Ministry of Defense in India that "in the year 1962, India had occupied 3,000 square kilometers of territory on the western sector" (Mullik, 1971).

Figure 1: Showing Border Clash between India and China

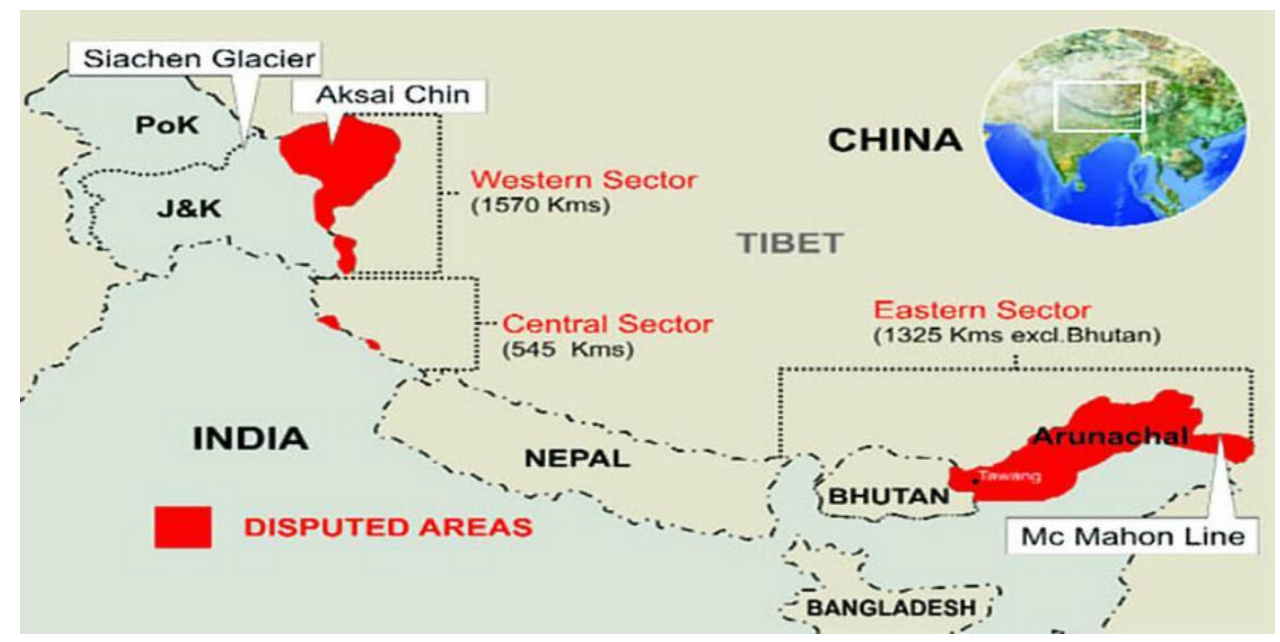

Source: https://www.clearias.com/india-china-border-disputes/

As for map shows, in 1962, the conflict between India and China turned into a bigger conflict in which the former had to face a defeat. China, with a strong army, had given a befitting response to India in this war. Over time, this situation was pacified by mutual visits. History shows that from 1963 to 1988 , both the countries expedited the process of visits to bring peace and stability after the conflict.

Historically, the problem of the border was unresolved by the British. They, after leaving the subcontinent, did not demarcate the border, hence, it later on culminated into a full-fledged war between two neighbors (Gyaneshwar, 1991). It was obvious that these conflicts had left a deep impact on India and China. Both countries have tried their best to resolve that issue. As one of the Indian experts said that "Keeping in view peace efforts, British India, Tibet, and Peoples Republic of China drew up an agreement at Shimla (province of Himachal Pradesh) in 1913-14" (Nathan \& Vinod, 2000). The agreement on borderlines was termed as ambiguous. However, the lack of clarity on this issue invited the attention of the Chinese leadership. The Chinese representatives were pressurized by their central government (Mansingh \& Nanda, 1990).

The relations between China and India saw their heyday in the 1950s. During Bandung Conference (1955), their relations began to be phrased as Hindi-Chini Bhai Bhai. Their political and territorial issues were put on the 
back burner. According to Lieu Xuecheng, a friendship between the two countries had an overwhelming impact on their overall relationships. Both were preoccupied with domestic and global problems (Xuecheng, 1994). But after a few days, old issues again cropped up. China was not on the same page with India on certain issues. Out of blues, China sent its army into Tibet. Dalai Lama in 1971 signed an agreement with China. He agreed on the 17 points agenda. In the words of Shakya Tsering (1999), Chinese control over Tibet transformed from Defacto to Dejure.

The integration of Tibet with China was aimed at countering some prominent sects. These steps left a wrong impression on India. It surprised Nehru too. India took measures to bring in its orbit countries like Nepal, Bhutan, and Sikkim. In this regard, China was asked to keep a low profile over this issue. As time went on, Nehru decided to give Tibet to China. This approach of Nehru was praised by China. Hence their ties again came back to its right track. Nehru was no more interested in war with China. He thought that minor conflict at the border could turn into a conflagration. Despite this, as pointed out by Sharma D Shalendra 2010, despite their peaceful ties, there are still chances of conflict between them (Shalendra, 2010).

In the backdrop of boundary issues and mutual exchange of visits, a brief lull was observed on both sides. On $11^{\text {th }}$ April 2005, India and China charted the course to resolve their political and territorial disputes amicably. Article 1 to 7 of the charter showed that they will strive for respect for each other, step by step approach in resolving issues, understand each other's sensitivities in strategic, security, and towards border areas. These principles in the charter seem to be their guiding principles upon which they can move forward. However, these principles, later on, appeared to be mere rhetoric than reality. Laura Zhou, in her article in South China Morning Post, June 5, 2018, noted that: "India's relations with China had "many layers". And despite their months-long military stand-off on the Doklam plateau last summer, "Asia and the world will have a better future when India and China work together in trust and confidence, sensitive to each other's interests" (South China Morning Post, 2018).

After Wuhan's engagement in 2018, their relations have worsened. The current military conflict at Ladakh (Galwan Valley) (2020) has created a lot of mistrust between the two Asian giants. Their conflict in the Himalayan region triggered off due to infrastructure development along the border. This shows how often their relations have pushed towards cooperation and conflict. 


\section{Reluctant Economic Embrace}

The relations between the two countries are intertwined economically too. The nature of their trade seems to be heavily lopsided. For example, both states are interdependent in terms of trade. Trade figures showed that in 2005, their trade got increased by almost thirty-seven percent. China has replaced Japan in terms of trade with India. If we look back to 2005, India was considered as the top destination for trade by China and the US, in which India happens to export around eighteen to nine percent to these states. Similarly, India has also been seen as one of the top priorities for major imports from China as well as the US. Trade statistics in the year 2005, showed that China relies less on Indian trade. For instance, trade between the US and China was amounted to \$ 204.7 billion, whereas, the similar trade of China with Japan amounted to $\$ 189.4$ billion. Hence, looking at China's trade figures with India indicated $\$ 18$ billion. In this sense, India was considered as one of the sixteenth largest and 13th biggest importer of products from China in the year 2005 (Rusko \& Sasikumar, 2007).

The political relations between both countries have been lingering for decades yet their economic cooperation is increasing gradually. If one looks at the current trends in the export and import index, India is faced with the challenge of increasing trade imbalances with China. Trade figures showed that India seems to have been continuously faced with uneven trade that mounted to a whopping $\$ 46.56$ billion last year. However, at the same time, Indian exports to China are decreasing. Thus, leading to a marginal improvement by $2.1 \%$ to nearly $\$ 71$ billion.

Trade figures showed that China and India's trade in the year 2016, amounted to $\$ 70.8$ billion. It seems that there was a decline of $2.1 \%$ as was reported by the General Administration of Customs. Moreover, China's exports totaled $\$ 58.33$ billion. It means that there was an increase of $0.2 \%$ compared to $\$ 58.25$ billion in 2015 . The year 2015 , saw the declining trend of trade between India and China, for instance, the exports from India to China fixed at $\$ 11.76$ billion, about $12 \%$ decline compared to 2015 . The exports by India showed a downward trend from $\$ 16.4$ billion in 2014 to $\$ 13.38$ billion in 2015. similarly, it was noted by the trade analysts that in 2016, the trade deficit between India and China increased up to $\$ 12.46$ billion. In addition to this, Vrishti Beniwal, (2012) an Indian journalist for Bloomberg News, wrote an article, "Backlash against Chinese products ramps up in India", published in Bloomberg. Her study acknowledges that there is an increasing gap in trade between India and China. She explains the economic trade imbalance in the chart.

As indicated in Table 1 that there is a huge gap in exports and imports between China and India. It is said that there happen to be a flood of goods from the Chinese side to India than Indian goods into China. Given this gap, the government of Modi is not happy with such development. The trade deficit between China and India is creating an uncomfortable situation for India, in particular. India, in the backdrop of these trade gaps with China, has started an 
economic restructuring plan. New Delhi by this time seems to be serious and keeps it on the high priority list.

Table 1

Showing India-China Bilateral Trade (figure in billions)

\begin{tabular}{|l|l|l|l|l|}
\hline Year & $\begin{array}{l}\text { Exports by } \\
\text { India to China }\end{array}$ & $\begin{array}{l}\text { Imports by } \\
\text { India from } \\
\text { China }\end{array}$ & $\begin{array}{l}\text { Trade } \\
\text { Imbalances }\end{array}$ & $\begin{array}{l}\text { Total } \\
\text { Trade }\end{array}$ \\
\hline 2014 & 16.41 & 54.24 & 37.83 & 70.65 \\
\hline 2015 & 13.4 & 58.26 & 44.86 & 71.66 \\
\hline 2016 & 11.75 & 59.43 & 47.68 & 71.18 \\
\hline 2017 & 16.34 & 68.06 & 51.72 & 84.41 \\
\hline
\end{tabular}

Source: Indian Embassy in China cites from General Administration of Customs, China

Given the frequent exchange of visits at the state level, their mutual trade sought a great boost. After the revival of their trade in 1984, their trade was hardly reached two million dollars. However, these business-oriented activities had benefitted from the people living near the border areas, for instance, Shipki La and Lipulekh La corridor. Realizing the peace and development around adjoining border areas, both countries came forward to open a Nathu La pass in 2006.

After the Chinese entry into World Trade Organizations (WTO) in the year, 2000, and the increasing trust of India for the Chinese implantation and commitment to her norms and values had to enhance their mutual business. India also took measures to enhance its economic performance, develop its infrastructure, besides developing its communication and shipping lines. Due to efficient trade management and reforms, their trade amounted to 24 USD in 2006. This ratio of trade increased up to USD 60 billion in the year 2010. They had set their trade target to be achieved in the year 2015. Indian business community took a keen interest in Chinese trade fairs. Their objective was to achieve the maximum targets of their trade export. Their interest was visible in the agriculture, pharmaceutical, and IT sectors (Joint Communique, 2010).

China responded with its investment in the Bauxite industry, steel, electronics, and manufacturing sectors in India. Moreover, India was also interested to learn from the Chinese expertise in roads and railway development. Most of the Indian investment in China could be found in different sectors, including pharmaceutical, information technology, and financial services. In December 2010, Wen Jiabao was accompanied by a group of Chief Executive Officers (CEOs) during their visit to India. After this meeting, a new joint forum was established which was named as CEO Forum. It aimed to enhance cooperation through banking sectors. Moreover, their cooperation in IBM and General Electric were bridge builders between China 
and India. As expressed by one of the experts of Harvard, Khanna, that their collective impact is huge as compared to any country in the world (Khanna, 2007). It is a very well-known fact that there is a huge potential in China-India economic trade and commerce. Their people to people interactions could be a major leap forward in their ties in the future.

\section{India's Look East Policy (ILEP)}

India's Look East policy was advocated by two the then Prime Ministers of India, P.V. Narasimha Rao (1991-1996) ad A.B. Vajpayee (1998-2004). The purpose of India's Look East Policy (ILEP) was to create a friendly environment in which foreign trade and investment could be attracted. There is also an 'Act East Policy', that also reinforces India's cultural, strategic, and economic ties with the East Asian countries.

Experts believe that India's 'Act East Policy', and 'Look East' are not different. These two are considered to be two sides of the same coin. It reinforces India's approach and strategy towards the Asia Pacific region (Kesava, 2020).

In addition to this, ILEP prioritizes India's economic and comprehensive strategic linkages with the Southeast Asian countries. These approaches help India to serve its interests like counterweight and contain the increasing influence of China. In contrary to an Indian approach, Beijing generally discourages the presence of India in its backyard. Despite this, analysts argue that "China is aware of the various cultural and spiritual ties that India shares with Southeast Asia, which could naturally attract the two regions to come closer. China knows that India is the only country that could challenge its ascendancy and potential hegemony in Asia" (Strachan et al., 2009).

Since the N. Rao initiative, the Indian government has pursued such a policy which has attained success by enhancing friendship and cooperation with many East Asian Countries, Such as Myanmar, Malaysia, Vietnam, Philippines, Singapore, Thailand, and Japan. India has enhanced her relations in the economic, cultural, and military sphere and she has conducted joint Naval exercises with east Asian countries. This move has been criticized by China.

Indian naval exercises with Vietnam in 2000, the Joint petrol initiative with Singapore in 1993, and Indonesia in the Andaman Sea in 2002 are seen by China as India's flexing its muscles. India's enhanced co-operation with these states and continued engagements in the South China Sea are clashing with China's interests. The Southeast Asian region holds enormous potential in economic and energy sectors, therefore it is determined to tap that potential to access cheap and easy resources. Instead of Southeast Asian states move into the Chinese sphere of influence, India is making efforts to bring them to their side (Frankel \& Harding, 2004). By establishing a Naval base at Andaman Nicobar Island, New Delhi will open up doors for her to Southeast Asia. While China believes that its domestic, regional, geopolitical, and 
economic reform will require her to plan strategic adjustment (Gangchen, 2007).

The Malacca strait is important for Indian cargo and its shipment to the world. Most of her trade, raw materials, oil, and gas pass through this route. What adds to Southeast Asia's importance is its potential as a major supplier of raw materials and its huge market for goods. These facts make Southeast Asia a very attractive region for countries with economic interests. Similarly, increased and enhanced co-operation with Southeast Asian countries will strengthen India's economy and security within the region (Takenori, 2006). Indian analysts think that the participation and partnership of India with ASEAN is seen as an opportunity (Stephen, 2005).

\section{Maritime Security}

The Indian Ocean being $3^{\text {rd }}$ largest Ocean in the world holds great strategic importance from trade, commerce, energy security, imminent threats from pirates, terrorism, and access to raw materials. These realities increase the importance of maritime security to deter threats, such as nuclear proliferation, terrorism, human and drug trafficking, and pirates. Maritime security has attracted great attention from regional and global powers. To avoid any unwanted incident, security is deployed at strategic locations to ensure the peaceful movement of goods and services across the Ocean.

Asia, one of the most populous continents with 3.9 billion people, is growing economically. To ensure its continued growth to meet the needs of their people, these states require unhindered access to oil and gas and raw materials for their industries. The Indian Ocean as a major navigation channel and supply route carries great importance in ensuring a continued supply of raw materials, apart from that Indian Ocean services as a source of connecting with regions, Such as the Middle East, Africa, and Europe. The emerging challenges, such as governance issues, environmental problems, territorial disputes, terrorism, militancy, and pirates have frustrated the policymakers. Both China and India are faced with a similar threat. Somali pirates are a constant problem in the Indian Ocean, which threatens the unrestricted supply of natural resources from other regions. Increased population in China and India requires increased industrial production and growth which in turn is heavily reliant on the supply of raw materials. Such a situation is a constant source of tension for both countries.

Therefore, to ensure safety and security at maritime for their supply line, both countries need to chalk out a plan to ensure security for energy corridors and raw materials. China's emerging role as a global power is leading her capabilities beyond the region. Her intentions are not limited to the Middle East, South Asia, Central Asia, or Southeast and Fareast Asia but beyond that to Africa and Europe. China's military modernization and her claims to the South China Sea Have resulted to provoke Japan, India, and America. This regional geopolitical instability, political ups and downs, and tensions among nation-states could lead to civil wars, food crises, insecurity in littoral states, 
which may result in a conflagration. This conflict will resultantly hinder the smooth running of trade across the sea. Keeping because of these threat perceptions and insecurity, China has initiated the "String of Pearls" policy.

\section{Discussion}

It appears from the above analysis that various powers in the region are not only vying but jostling and envying with each other for smooth access towards energy resources, leverage in the region, protect and secure their trade through sea lanes. China needs unhindered access and supply of the new market, energy resources, safety, and security of its sea lanes. In this sense, China has developed ports "String of Pearls", intending to advance her geo-economics, trade and investment, peace, and development in the region. Somehow, India's policy dynamics show that it is strategically autonomous. This can be seen from India's tilt towards Russia and their deepening ties with the USA. Indian analysts know that their long-term engagement with Russia and America may not serve its core interests in the long run. This strategic thinking reflects that New Delhi may not put its all eggs in one basket. Hence, today or tomorrow, their choice will remain only China with whom they have to develop their rapprochement. This thinking prevails among the Indian strategists given their deeper understanding of Indian traditional norms, its territorial vastness, and the ever-increasing second largest population in the world. Similarly, President Xi Jinping at BRICS Summit, at Xiamen, China on $5^{\text {th }}$ September 2017, stated that Beijing wants to have its relations on the right track in the backdrop of their Himalayan border standoff. He further maintained that "China and India must maintain the fundamental determination that each other constitute mutual development opportunities and do not constitute a mutual threat," Xi said, adding that peaceful, cooperative relations were the "only correct choice" (Reuters, 2017).

\section{Conclusion}

In this article, we focused on how China and India have evolved since the post-cold war period. Then, we examined the important factors in the engagement and estrangement of their relationship. This paper showed that India is unlikely to move towards an alliance with China. Anti-China perception in India still exists. They consider China as a rival in Asia. The Indian policy strategists on China exercise three C's: Competition, Cooperation, and Caution. Sonia Gandhi, in her visit to China in 2007 had said that "the foundation of India-China relation is based on mutual trust and pragmatism". Unless India focuses on its development, poverty alleviation, and robust foreign policy, it is expected to have less leverage in Asia and will remain as a junior partner to China. Indian policies towards East Asia, and in South Asia reflects their care and caution. At the same time, these policies also show engagement and hedging in the region. Since both regional powers are trying to jostle, engage, disengage, reengage, the road ahead seems murky and bumpy. Therefore, this study suggests that it is in mutual interest, peace, 
stability, and prosperity of India and China in particular, and region in general, to engage constructively, keeping in view political and territorial sensitivities of each other.

\section{References}

Bhalla, A. S. (2000). Uneven Development in the Third World: A Study of China and India. London: The Macmillan Press Ltd.

Frankel, Francine \& Harry, Harding. (2004). The India-China Relationship. Columbia University Press.

Garver, John W. (2001). Protracted Contest: Sino-Indian Rivalry in the 21st Century. Seattle University of Washington Press.

Gangchen, Zhao (2007). The Development of India's Look East Policy and its Significance, Contemporary Asia Pacific, 17, 813-821.

Chaturvedi, Gyaneshwar. (1991). India and China relations: 1947 to Present. Agra: MG Publishers.

Harimoto, Takenori (2006). The World as India Sees It, Japanese Perspectives on Foreign Policy. Vol 6, no: 3, 6-7

Pant, Harsh V. (2018, May 1). "Modi and Xi in Wuhan: Bringing Normalcy Back to the India-China Relationship" The Diplomat. Retrieved from https://thediplomat.com/2018/05/modi-and-xi-in-wuhan-bringing-normalc y-back-to-the-india-china-relationship/

Hoffmann, Steven A. (1999). India and the China Crisis. London, England: University of California Press, Ltd.

Indian Ministry of External Affairs, (2011, January) Foreign Relations, China, Retrieved from, http://meaindia.nic.in

Joint Communique (2010). Joint Communique of the Republic of India and the People's Republic of China, New Delhi, 16 December. Retrieved from http://meaindia.nic.in.

Kesavan, K.V. (2020, Feb 14). India's 'Act East' Policy and Regional Cooperation, Observer Research Foundation, India. Retrieved from https://www.orfonline.org/expert-speak/indias-act-east-policy-and-regional -cooperation-61375/

Khanna, T. (2007). Billions of Entrepreneurs: How China and India are Reshaping their Futures and Yours. Cambridge, MA: Harvard Business School Press,

Xuecheng, Lieu (1994). The Sino-Indian Border Dispute and India-China relations. Lan Ham, M.D: University Press of America.

Mansingh, Surjit \& B.R Nanda. (1990). India and the US. Indian Foreign Policy: the Nehru Years. New Delhi: Sangam Books.

Mansingh, S. and Levine S. (1989). China and India: Moving Beyond Confrontation, Problems of Communism 38, No. 2-3, 30-49.

Lionel, Martin (2004). Mistrust and cooperation: Analysing Sino-Pak Relations, Asian Research Journal. Volume VII, 12-18.

Maxwell, Neville (1981). India's China War. New York: Pantheon. 
Mullik, B.N. (1971). My Years with Nehru: the Chinese Betrayal, New Delhi: Allied.

Rusko, C. J., \& Sasikumar, K. (2007). India and China: From Trade to Peace? Journal of Asian Perspective, Vol. 99/123, 110-117.

Nathan, Rang CV. \& Vinod, Khanna, C. (2000). India and China: The Way ahead After, Mao's Indian War. New Delhi: Har-Anand Publications.

Shakya, Tsering. (1999). Dragon in the Land of Snows: A History of Modern Tibet, since 1947, Pinlico. London.

Sharma. D, Shalendra. (2010). China and India in the Age of Globalization. Cambridge University of Press.

South China Morning Post, (2018). Indian leader Modi wants no part in China US rivalry. from https://www.scmp.com/news/china/diplomacy-defence/article/2149237/ind ian-leader-mo di-wants-no-part-china-us-rivalry-still

Stephen, J. Blank. (2005). Natural Allies, Regional Security in Asia and Prospects for Indo-American Strategic Cooperation. Carlisle Penn: Strategic Studies Institute. US Army War College.

Strachan, A. L., Kang, H. K., \& Sinha, T. (2009). India's look East Policy: Critical Assessment. Interview with Ambassador Rajiv Sikri'. New Delhi: Southeast Asian Research Programme, Institute of Peace and Conflict Studies.

Beniwal, Vrishti (2017) Backlash Against Chinese Products Ramps Up in India, Bloomberg Retrieved from https://www.bloomberg.com/news/articles/2017-11-02/made-in-china-swa mps-modi-s-pland-as-backlash-spreads-to-streets

Wagner, C. (2016). The Role of India and China in South Asia, Strategic Analysis, 40(4), 307-320. 